\section{Effect of Histidine on the Urinary Excretion of 4-Aminoimidazole-5-carboxamide}

We have rocently shown ${ }^{1}$ that pationts with folic acid and/or vitamin $\mathbf{B}_{12}\left(\mathbf{F A}-\mathbf{B}_{12}\right)$ deficiency have an increased excretion of 4-aminoimidazole-5-carboxamide (AIC) comparod with anaemic pationts who are not so deficiont, or with non-anaemic hospital patients. A FlGLU tost, using an oral load of $15 \mathrm{~g} \mathrm{~L}$-histidine hydrochloride, was performed on many of these patients as a diagnostic procedure; sinco a haematological response has been observed in such patients following histidine dosage ${ }^{2,3}$, which would imply a partial correction at least of the disordered nucleoprotein metabolism present in these deficioncies, we have taken the opportunity to investigate its effect on tho urinary excretion of AIC, itself an intermediary in purine synthesis. For this purposo urine passed between 4 and $8 \mathrm{~h}$ after histidino dosage was examined (Period 3) ; urinos collocted during one hour in the morning immediately before the test (Poriod 2) and in some cases for a similar 5 -h poriod tho previous afternoon (Period 1) served as controls. For comparison, similar collections were made from 8 normal adult volunteers and 3 pationts who had anaemia not associated with FA-B B $_{12}$ deficiency. No dietary rostrictions were imposed during the test. Urinos were preserved with $1 \mathrm{ml} .6 \mathrm{~N}$ $\mathrm{HCl}$ per $\mathrm{h}$ of the save and stored at $4^{\circ} \mathrm{C}$. AIC was determined by an ion-exchange chromatographic technique ${ }^{4}$. In order to minimize any errors in the timing of the urine collections all results were expressed as $A I C \mu \mathrm{g} / \mathrm{mg}$ creatinine.

Table 1 shows the mean AIC excretion in the two groups. In the 11 subjects without FA-B ${ }_{12}$ deficioncy the excretion was significantly less in Poriod 2 than in either Periods 1 or $3(P<0.01$ in each case), but Periods 1 and 3 did not differ significantly. We therofore conclude that histidine does not normally affect AIC excretion and regard the low valuos in Poriod 2 as resulting from the diurnal variation reported elsewhere ${ }^{4}$. In tho 11 patients with $\mathbf{F A}-\mathbf{B}_{12}$ deficiency whero excretion in all three periods was moasured, no statistically significant difference in excretion was found between these poriods. In these subjects, however, values wore slightly lower rather than higher in Poriod 3 as compared to Period 2. Inclusion of an additional number of subjects from whom urine was collected only over Periods 2 and 3 raised the total to 26 , and the fall in AIC excretion during Period 3 was shown to be significant at the 2 por cent level. We thereforo provisionally conclude that histidine does produco a fall in AIC excretion in subjects with FA-B B $_{12}$ deficiency. How ever, the study of larger and more sharply defined subgroups within this broad classification would bo desirable, as would further information on diumal variations in the excretion of AIC and croatinino.

All the abovo subjocts with $\mathrm{FA}-\mathrm{B}_{12}$ deficiency showed, by virtue of an increased excretion of formiminoglutamic acid and/or urocanic acid following histidine, evidence of a dofoct in the motabolism of $\mathrm{C}_{1}$ units. It is difficult to visualize any role for AIC in purine synthesis in man which does not involve $\mathrm{C}_{1}$ units, and we consider that this mota. bolic defect must account at least in part for tho high excretion of AIC in such subjocts, reported previously'. The provision of an incroased number of potential $C_{1}$ units in the form of histidine might woll, as a mass action effect, promote a more efficient utilization of AIC, accompanied by a decrease in its excretion. The resulting increase in purine synthesis might provide a basis for

\begin{tabular}{|c|c|c|c|c|}
\hline & $\begin{array}{c}\text { No. } \\
\text { subjects } \\
\text { tested }\end{array}$ & $\begin{array}{c}\text { Pre-hi } \\
\text { Period 1 }\end{array}$ & $\begin{array}{l}\text { Period } 2 \\
\text { (morning) }\end{array}$ & $\begin{array}{c}\text { Post-histidine } \\
\text { Period } 3 \\
\text { (afternoon) }\end{array}$ \\
\hline \multirow{2}{*}{$\begin{array}{l}\text { Normals and non-deficient } \\
\text { anaemic patients } \\
\text { Folie-dcid and/or vitamin- } \\
B_{19} \text {-deficient } \\
\text { patients }\end{array}$} & 11 & $0.62 \pm 0.029$ & $0.50 \pm 0.029$ & $0 \cdot 65 \pm 0 \cdot 029$ \\
\hline & $\begin{array}{l}11 \\
26\end{array}$ & $2 \cdot 09 \pm 0 \cdot 120$ & $\begin{array}{l}1.84 \pm 0.120 \\
2 \cdot 20 \pm 0.164\end{array}$ & $\begin{array}{l}1.77 \pm 0.120 \\
1.59 \pm 0.164\end{array}$ \\
\hline
\end{tabular}

explaining tho haematological response noted in megaloblastic anaemia following histidine dosage.

If the high rate of excretion of AIC in anacmia is re. garded as due to an impairment in the formylation of AIC ribotido in the absence of adequate quantities of folic acid, as occurs in sulphonamide inhibited micro-organisms, our experimental findings would all appear to be adequately accommodated. If this were the only abnormality, however, an overall depression of purine synthosis would be implied, wheroas the exact opposite appears to be the caso as judged from rocent studies. The finding that patients with vitamin $\mathrm{B}_{12}$ deficiency, for example, excrete a smaller than normal percontage of orally administored ATC has led to the suggestion that intorference with feedback control of purine synthesis may mean that the shunt mechanism of by-passing nucleic acids in purino biosynthesis is functioning at a rate well abovo normal in these subjects ${ }^{5}$. Interpretation of AIC cxcretion is further complicated by the possibility that AIC might be a product of purine degradation. If such degradation woro inhibited by histidino, as has been shown to occur in microorganisms ${ }^{6}$, the effects of the latter on the haematological status and on the excretion of AIC could bo explained.

We thank Miss H. M. Ferres for statistical analysis.

Department of Chemical Pathology,

J. E. Middie'Ion

Group Pathology Laboratory, General Hospital, Southampton.

R. F. COWARD

P. Sмiтн

Biochemistry Department,

Royal Air Force Institute of Aviation Medicine, Farnborough, Hampshire.

${ }^{1}$ Middleton, J. E., Coward, R. F., and Smith, P., Lancel, ii, 258 (1964). a Chanarin, Y., Brit. J. Haematol., 9, 141 (1963).

${ }^{3}$ Rundles, R. W., and Brewer, jun., S. S., Blood, 13, 99 (1958).

4 Coward, R. F., and Snith, T'., Clin. Chim. Acta (in the press). ${ }^{5}$ Herbert, V., Strelff, R. R., Sullivan, L. W., and McGeer, P. L., Lancet, ii, 46
(1964).

- Martin, R. G., J. Biol. Chem., 238, 257 (1963).

\section{Lathyrism and 7,12-Dimethylbenzanthracene- induced Carcinoma in the Rat}

The lathyritic agent, $\beta$-amino-poprionitrile (BAPN), reduces the tensile strength of mesenchymal tissue and modifies the collagen content ${ }^{1,2}$. Since local tissue factors are believed to be of importance in tumour growth, BAPN was administered to rats in which tumours were induced by a polycyclic hydrocarbon. 7,12-Dimethylbonzanthracene (DMBA) was used because it regularly induces mammary carcinoma in young fernale Sprague-Dawley rats. The strain of rat, the age, and the hormonal status are important factors in the induction of mammary carcinoma 4 .

50-day-old female Sprague-Dawley rats were given a purified diet with or without addition of 0.5 per cent BAPN. $20 \mathrm{mg}$ 7,12-dimethylbenzanthracene in sesame oil was administered intragastrically at the beginning of the experiment in a single dose ${ }^{3}$. The time of induction, rate of growth and number of tumours were noted for $\mathbf{1 5 0}$ days. Urine samples were collected at $60-70$ days after the beginning of the experiment. Oestrogenic substance was extracted, chromatographed on a 3.5 per cent hydrated alumina, and measured by a micro-Kober reaction ${ }^{5,8}$.

The animals were divided into three groups: (rroup I, intact female rats; Group II, DMBA; Group III, DMBA and BAPN. The lathyritic rats (Group III) developed tumours at an earlier stage than the control rats (Group II). The tumours in the lathyritic group grew faster and the total weight of tumour mass was significantly greater than in the Group II rats. Lathyritic rats did not show any significant increase in the number of tumours. The results are summarized in Table 1. 